\title{
Refugees and Bioethics
}

\author{
Darryl MACER ${ }^{a}$
}

\section{Migration is a feature of human beings}

Homo sapiens are considered to be one of about 30 upright standing hominid species that have lived on the planet earth. It is implicit in our very nature to migrate, to move around the planet as seen in our physical body structure - hunter-gatherers with an ability to run long distances. Whether we wander to find a new source of food, a new environment, to look for new ideals, to search for God, or just to find a new source of water and safe environment for us to live, we migrate. All Homo sapiens have originated from Africa and were migrants, at one point refugees, so the recent attention to the migration of people from conflict areas in the Middle East towards new more peaceful horizons is in one sense nothing new in the history of humankind. On the other hand, as we developed agrarian societies with complex social and technical structures, building villages and townships with an established physical infrastructure provides protection and stability. Different types of culture emerge, and nowadays there are few nomadic societies compared to those which are stable.

Turkey is at the crossroads of Europe and Asia, and is a transit point for this traditional migration between Europe and Asia and Africa. There was much migration of people in both directions. Genetics tells us that after the initial migration out of Africa, for some reason, some of the Europeans in Europe then migrated back to Africa in different periods, ranging from 30,000 to 1,300 years ago. The genetic evidence is clear, and perhaps this flow back to Africa was caused by climatic conditions such as an Ice Age. We can see the presence of Neanderthal and Eurasian genetic markers in African tribes. We see migration of Southern Europeans back to South Africa about 1,300 years ago, in the Khoisan populations (1). These are southern African hunter-gatherers and pastoralists who speak non-Bantu languages with click consonants. One involved populations related to Niger-Congo-speaking African populations, and the other introduced ancestry most closely related to west Eurasian (European or Middle Eastern) populations. A similar signal of west Eurasian ancestry is present throughout eastern Africa, in the history of Kenyan, Tanzanian, and Ethiopian populations, which are dated to 2,700-3,300 years ago.

Climate refugees appear to be an old and longstanding condition of our existence in terms of geological ages. We can see this at times of ice ages, also when there was the presence of land bridges between continents such as the Bering Straits bridge which appears to the route that Asians took to become Americans, about 20,000 years ago. This global migration was also seen into the continent of Australia much earlier. It is not even unique to Homo sapiens, but the presence of Homo erectus skeletons and remains of tools all across the world shows that migration was a feature of some other hominoids as well.

The reasons for migration of persons because of ideological reasons is also seen and we can find some evidence in history for this, in the spread of Jewish populations into India and Japan about 1900 years ago after the sacking of Jerusalem. There is archaeological evidence and in some cases still living villages which are evidence of this ideological migration. The migration of ideas is something which flourished in the cross-cultural pursuits of science and philosophy, subjects which have greatly influenced bioethics. In the history of medicine we can also see migration of ideas, concepts of health and disease, migration of technology, and wisdom.

\section{Communal boundaries}

On the other hand communities may like to have clearly defined boundaries, and religious groups have provided one form of society building. From that logic, it is no wonder therefore that contemporary societies often see people expressing ideas of what is the status quo for one particular region. They like to

a President, American University of Sovereign Nations, Arizona, USA $₫$ darryl@eubios.info 
name their group, and create a governance structure, with a chief and followers, and often different occupations are delineated. Some of these modern communities may not be indigenous in terms of a long history, and may be different genetically and philosophically from the original peoples that lived in that land. For many people the challenges to their accepted faith pattern, or to their religion, their belief system, brought through migration of ideas is frightening. Often migrants have been excluded from living peacefully in the new land because there seemed to be the other, "them" not "us", and some communities feel threatened by the new persons.

When the numbers of migrants are large, as seen in the colonization of the Americas by the Europeans, and they have military might and power, they can overrun and destroy the indigenous community. Although the community may at first welcome the new persons, as seen in the welcome of the English by the first tribes that entered North America, soon this harmony and agricultural assistance was repaid by violence. A few centuries later we can see broad distrust of the "White" European dominant society among most Native American populations, based on a $90 \%$ population decline in the indigenous American populations caused through this immigration (4).

\section{Nation States}

In the case that might is right we can see military power dominates all other conditions, such as love and compassion. Recognition of human rights provides us with a real alternative to consider the way that we can shape and mold a new society, and the New World order. Ironically at the same time we have seen the emergence of consent for human rights there has also been increasing focus on national sovereignty, where the boundaries of the country set for political and economic reasons, often by European powers which had most recently colonized geographical regions, then decided that they can no longer control the peoples in that land through direct colonization and allowed them to make "nation states". Although the dominant countries may extend significant economic precious upon the people that remain in the new nations, whether we respect new nations or ancestral lines, they are not always clear communities that would naturally be living together under one national identity. Nationalism has not been an ideology that has had a wonderful consequence over history - in fact it provides so much blood through wars.

The existence of nation states as stable bodies is an ideal that some of peoples in the world are able to rejoice in. Being able to live in places which are relatively stable or clearly delineated through historical and/or geographical boundaries is a luxury found in few places. Very few states have not been colonized, we can think of Japan, Nepal and Thailand as three examples. Japan was an island, that was strong enough and distant enough four hundred years ago to resist the first wave of Europeans. It had conceded to American pressure 150 years ago, but is proud of its history. Nepal as a mountain empire could also resist colonization, through strong military might. Thailand seems to have survived through diplomacy and gave land to the English and French in return to autonomy. However significant portions of the Thai population have Chinese blood, and we could see this as a genetic mixing, the same as noted above for the mixing of European and African blood lines as seen in tribes in parts of Africa. This has implications for bioethics of race - some societies have apparently managed to avoid some of the extreme forms of racism that have dominated some lines of thinking on migration.

One of the features of a stable society is that it should distill equilibrium amongst its population, despite the divisions of the world caused by invaders, be they Mongolians, Ottomans, Europeans or other colonial powers. Struggles for power occur within every society, so it is no surprise to see wars and conflicts between different societies. Respect for persons, and their human rights, has been tied to the emergence of democracy. Direct democracy is something we are still striving to perfect, but is now practiced in many parts of world. We can see tolerated differences over time in the inclusion of the group who has human rights, for example, democracy in Ancient Greece was for free men, not for slaves. Democracy in early United States did not include most Native American tribes or black slaves. Men held on to political power in most societies only giving it to women a century ago in most cases for patriarchal societies.

Respect for human rights is critical for the development of societies which can tolerate the other, in some form of democracy that is critical for the overall long term stability of the state. Bioethicists sometimes contribute to nation building, and we've seen the emergence of National Association of Ethics that 
provide voices to protect the weak. Most governments establish a Ministry of Culture, Ministry of Education, and other structures which attempt to inform young (and older) citizens how unique their nation state is.

\section{Human rights for protection of the migrant and indigenous persons}

Migration has been a great feature of the 20th Century where we have seen a growing world population fighting for limited resources and land, As we use the resources close by, and inside our national boundaries, and population grows, land and resources become so expensive that people must my trade in order to find food water, shelter, employment. Trade itself has been a feature and reason for communication between countries and cultures for millennia. The pragmatism of trade, as a preferred and more stable method for exchange of goods to war, reflects some hope in a bioethical heritage of nonmaleficence and justice that lie underneath the ideas of human rights.

It would be interesting to survey the willingness of countries to accept refugees versus their claims to a unique cultural identity. The relationship is not so clear. In the 2015 refugee crisis intro Europe we can see certain countries which we have been thought traditionally not to be so open to migration, accepting largest numbers of migrants. Perhaps the ease at which they accept countries may tie to economic development and conceive a growing population as also a growing market. It is one of the reasons that Germany has accepted so many refugees. Maybe the reluctance of Britain to accept so many refugees is because of there already diverse population base, a result of the return of so many British dependents and former second-class citizens of the British empire from the former colonies had been occupied across the world. On the other hand, countries like Canada are still trying to increase the population because of its large landmass, and it has been traditionally open to modern immigration waves.

Eugenics has been one of the major topics in bioethics and it has had a long link to immigration. In 1904 Charles Davenport and colleagues in New York in the eugenics movement helped shape immigration rules and quotes with racial and eugenic stereotypes (2). These types of eugenic immigration quotas are actually still in place in most countries in the world, offering easier access for more qualified, possibly more intelligent, or persons of some extraordinary ability. This system may work to some degree for the elites in a society, and in times when there is not chaos or war in the country, but the Syrian conflict is a chaos that demands us to protect the human rights of the victims. Turkey can be applauded for taking millions of refugees, and providing free education to the children. The revision of normal rules, such as the relaxation of official residency requirements to attend school, simply allowing children to attend school because they are human beings, is a positive consequence of a calamity for the migrants.

Eugenics is not the same as ideological screening of immigrants. We can see some people focusing on religion as the determinant of entry for an immigrant into a new country. Some of the concerns against Muslims have been the linkages to radical jihad which has been associated with a number of terrorist activities, but this is not the only religious group which has been linked to terrorism. The Irish Republican Army and the disputes between England and Ireland had to decades of violent protests and disputes between Catholics and Protestants in Northern Island. Both these radical groups used terror as a method to try to become stronger. In Sri Lanka there was vicious fighting between Tamil Tigers and the Sinhalese population majority, even though from outside we wonder why they see themselves as ethnically and religiously different. Even as in the case of Ireland where people come from the same genetic stock, they are the same ethnicity, it makes us question how people can form identities so strictly enforced and kill others, and even genocide as seen in recent times in Europe, African and Asia. The Civil War of the United States was one of the bloodiest conflicts, yet similarly a stupid exercise of military might. Some claimed it was fought for human rights to free slaves, but nothing is so simple. Any language to attempt to justify war must be questioned in light of what history has told us.

National social welfare services and health insurance systems have also been linked to citizenship in most cases. In some senses it's rather ironic that if we claim that we respect the human rights of people, we ask people in our land for an identification number as a proof of citizenship before we will treat them. Of course there are some medical migrants who will abuse the system. We could consider it is not just to those who paid taxes under the condition that the taxes will help support them when they need extra care, to spend that tax for people who have not paid into the system and come to the country simply because 
they require an extremely expensive medical operation. There are also some procedures no one will get reimbursed, even inside the same country, as the limited resources need to be shared between many needs. This body of bioethics literature on limited resources for the health system, and the duties to provide firstly access to treatment for people who paid for taxes can be useful for consideration of refugee emergency medical care. On the other hand solidarity and love argue that we treat all people based on medical need. Some of the refugees coming from conflict zones have particularly urgent medical needs that cannot be addressed in their homeland, so triage principles may be more useful. Exclusions of health coverage to some refugees could be seen as a necessary evil to allow the financially scarce and financially stretched national insurance system cope with a stretched budget, however, the ideals of socialism that are seen in most European countries mean that reasonable medical care is provided to all persons, regardless of their "papers". This is a sign of a civilized and bioethically mature society (3).

Interestingly, one of the principal ideas to have emerged in the opinions of countries which have accepted many immigrants in Europe in 2015 is the identification that there are "European values" that demand morally a society to accept immigrants coming from conflict and political oppression and to give them equal rights to the citizens of land. This sense of solidarity, a principle agreed upon by all countries of the world in the UNESCO (2005) Universal Declaration on Bioethics and Human Rights, is a welcome trend in dealing with refugees. We must hope that the impetus forced upon society by the refugee crisis reminds us of this sense of hospitality, solidarity, equity that has emerged not just in the midst of this refugee crisis, but in the millennia of migration and human movement.

\section{Minorities and discrimination}

Migrants have always been subject of discrimination, and discrimination is clearly one of the major challenges that slows integration of refugees into a new society. Will they become second-class citizens? Will they live in ghettos? These are issues that we must develop policy on and re-examine the impacts of the current policy before it is too late.

The recent influx of new refugees makes us also consider how we deal with the minorities inside our existing population. Some of these topics are politically difficult to discuss because of separatist movements that would shrink the size of the country - the so-called "nation" "state". Is there any country which is happy to see its land and population decreased because of separatism? I doubt it, but we have seen too much oppression of minorities, and we should not be surprised to see countries change boundaries over time. At the same time, we see the emergence of regional bodies such as the European Union and ASEAN, which recognize that all persons should be living together as one. The acceptance of new immigrants to a land to construct a vibrant and diverse society seems set to be a dominant current thought, but it can only work if we continue to fight all forms of discrimination against the "other".

One approach to examining in further detail the implications of refugee crisis is to use the framework of the Universal Declaration on Bioethics and Human Rights. According to many theories of bioethics, the principle of autonomy, self-determination, is critical to all moral theories. Therefore the decision to move, exercising this human capacity to walk and migrate around the planet, seems a very natural and ethical decision. In fact it is counter ethical to impose the border, a boundary to inhibit a natural human activity of migration. Would it not be a happier society if every person in the society is living thereby their free self-determination and choice to be present in that place and society? And those who are not happy with their present society can move to another community. This would be a world without boundaries or borders, without restrictive passports to freedom and exercise of autonomy. As long as autonomy was paralleled with responsibility to make a contribution to the community according to a reciprocal relationship that each individual has inside whatever society they live in, this seems to be almost an ideal. Some attempts to do this have been made for example, in the European Union, in the United States of America, and inside ASEAN. However, all those regions/states have borders, so our image could be something more like Malaysia, which has a very liberal and open border to most persons.

The limitations on exercise of autonomy through migration appeared to come from those who already inhabit the land. There is a human right to property ownership, to land ownership, and newly migrating people need to recognize the people who are living in the space already have a priority in being left to live in peaceful existence on that place. It can become very complicated however when ancestors of a different 
generation and sometimes even millennia lived in that place, as we have seen people migrating between different parts of the world, and some ethnic groups claim ancestral ownership of a particular land. Some people have been moved forcefully from the land through wars or colonial government structures. We can see hotbeds of conflict such as Palestine and Israel, when people claim their valid ancestral rights to the same lands as different generations lived in the same place at different times. Bioethicists can urge rational dialogue and respect for dignity in the construction of places were all can live in security. The attachment to a particular place and space is seen widely across the Pacific islands also - it is a universal principle, which is often balanced by the desire of some of the people to migrate.

Perhaps we can say that often people who have accumulated the greatest wealth inside the country have done so through corruption and soft/blatant extortion of poorer people. A balance needs to be made between the interests of those who have the land, and the persons who lost land through some unfit method of acquisition of land. On the other hand the right to own property based on the principle of working hard, means that some private individuals can accumulate wealth and can reasonably expect that wealth and land be passed on to their future generations. One can be cynical about how much some people desire equality, as Henri Becque, the 19th century French playwright wrote, "The defect of equality is that we only desire it with our superiors" (3).

\section{Environmental ethics}

Another particularly interesting issue with refugees is that migrants may move from crowded areas that have been preserved to protect wildlife and nature preserves such as national parks in the name of conservation. These national parks may have been areas where the people of a tribe lived traditionally. We see this in many African wildlife reservations, where people try to graze their cattle in the grasslands of wildlife refuges. For example, some of the Masai tribe in Southern Africa live close to many preserves. Because of population growth there is not enough grazing land left, climatic conditions also sometimes lead to loss of food for cattle, meaning they must move into the lush pastures and remaining savannah of a national park. When a hungry lion that naturally has a right to eat the cattle in this land, eats the cattle there maybe a conflict between the herdsmen who have grown the cattle and the conservationists who want to protect the lions. This human population explosion, overpopulation, is one of the great sources of movement of people today in the world. Land ownership should be given to other species, not only human beings, in an ecocentric perspective. This migration into conservation areas is another form of migration with tremendous implications over the dominance of one species on this planet, and the great losses to biodiversity.

Refugee animals are those who migrate across the world, and generally people permit cross species migration of animals. Sometimes border fences inhibit this. Migratory birds may escape such fences, and are an example of how the world has for a long time accepted a global society. However, fences and roads inhibit the free migration of animals across their habitats, and may threaten ecological stability.

\section{Ethical implications upon the refugee of being a refugee}

We can examine the impact of being a refugee upon the person himself. A refugee is a special class of migrant, as the term implies they have to leave the place they used to live because of a negative reason. Refugee includes a sense of helplessness that accompanies the need to have to move from a stable life stems from some underlying crisis that could be war, conflict, poverty, climate change, political or religious persecution, and other reasons that have driven the person into a sense of despair. Sometimes people will tolerate living with a sense of fear and threat to their family for many years because their identity is closely tied to one place. They balance losing land and their sense of place and belonging, versus the prospects of a better life in a new place. The degree to which people will tolerate persecution, injustice, poverty, famine and other threats to human security varies between people. Some sense of spirituality may be associated with attachment to a particular life and space. Persecution because of religious belief has been a source of movement for millennia. We can see, for example, the movement of Puritans and some other religious minorities from Europe to North America because of a perception that they could go to the "New World" to be free of the persecutions that had accompanied there being a challenge to orthodoxy in the place they lived. 
Sometimes the hesitance to migrate is because we are afraid of insecurity in the movement and we may also not be physically prepared for ensuring a hot (or cold) journey across sea and/or mountains. One set of refugees comes with acceptance and even with the provision of an air ticket provided by the United Nations or other Country schemes to relocate with people in an orderly and civilized manner, in a way which clearly preserve more of the dignity of the persons. The immigration criteria, as discussed above, may include some eugenic selection of talented persons, balanced with some humanitarian love for desperate cases, especially with the vulnerable such as children.

However, in the chaotic situation of war and refugee camps sometimes such luxuries of the correct papers are not possible or feasible. In some regimes it's impossible to get an exit visa. In some regimes it's not safe for consulates and embassies to the stationed therefore there's nowhere to get a visa. In other cases a sudden crisis that your house is bombed and you have nowhere to stay, means that the reason that you were staying in one place has suddenly gone. The sense that the most important thing is the right to life itself and to protect the loved ones around us, is something means that we are forced to become a refugee. While it can lead to a detachment from materialistic concerns which are common in our Modern age, it is a fundamental injustice the property has not been protected. It's inherently unjust that a family who had saved for their life and their parents loses everything, and they must start completely fresh - but this is a dilemma that immigrants face. So from this sudden lesson, that life is the most valuable thing we have, a refugee will be one who focuses all their human spirit to live. Such strong determination is important in the movement of refugees according to some primitive law of the jungle to survive, that others can through acts of mercy help them settle down in a new place and build up a sense of "normalcy" again that is important to see the expression of a common morality that we will love our neighbor as ourselves.

\section{The impact of refugees on the society around them}

Another perspective is how the presence of refugees are considered by those around them. First let's consider the community that has lost members because of the migration to another land. As we have seen once people started to move and if they are successful others around them will take the initiative and follow them. Following the footsteps of those who successfully migrated now provides some sense of new "home place" in a distant land. Very often we have seen interviews with refugees that that choice of target country is because their cousin or a relative is already living in a distant land, and that will determine the target because of the expected emotional and financial support at the end of their move from their land to a new place.

Another community is the community receiving refugees. If bioethics is the love of life than being able to give love to others, such as providing toys, food, water and other goods to newly arriving people is clearly something that will rebuild the receiving community and can in fact rebuild the sense of community identity of the receiving community. This seems to be the majority view in some countries which have received a large numbers of immigrants. In 2015 we clearly see "European values" in the acceptance of refugees. The fact that the number of refugees is said to be similar in magnitude to the refugees across Europe at the end of the Second World War is a reminder that conflicts have led to redefining identity and the meaning of love. The service for others and provision of love is one level critical for a just society. Another level is the forming of sustainable friendships with new "others" which have also been a feature some of the recipient communities. Some types of people rejoice in learning and sharing about different cultures, talking to people from the "other" group seems to be something that can lead to very significant development of a diverse national and an international community with tolerance, love and understanding, due in part to the refugee crisis. The irony here is that perhaps the hatred and selfishness that caused the war in one land, will lead to more love in another land. Sadly in the home land, hatred may become more engrained, unless people can help each other in that home community as well.

We must of course mention there are groups of people, generally a majority within the receiving country, who see the presence of refugees with the different religion as a great threat to the existence of "their" nation and their own cultural identity. We have seen the protests by some of these groups against migrants. Sadly we have also seen their association with some of tradition of Nazis which is a quite derogatory word for most people, but can be a turning point for some radical groups. Such groups are often linked to white supremacist ideas which are overtly racist. Such groups are clearly against a global society of freely migrating people, but see a global society of separatist and competing states. 
Wherever we see racism it is clearly divisive. How does it arise? It can appear in diverse communities as well as non-diverse communities. There are some communities that are essentially homogenous, for example, Japan. However if we look deeply we will see the Ainu people, the indigenous or aboriginal populations that show that Japanese people are not exactly homogenous. In the 19th century scientists from Japan wrote to the Royal Society in Britain to ask whether Japan should accept foreign brides from Southeast Asia to try to increase population. The Royal Society sent back the advice that importing women from Southeast Asia to become brides would dilute the Japanese gene pool and wouldn't be a good genetic solution. Clearly in 19th century Britain we can see there was an understanding among scientists that Britain was also homogenous society and those in colonies could be civilized by sending out British people to organize them. Interestingly the DNA sequences of some of the ancient Londoners that have been performed through DNA analysis have revealed that two thousand years ago London was already a multiracial society, with people from many different parts of the world living there. Probably this was a result of the Roman Empire with the migration of people for trade.

Certainly with the growing independence movement of people around the British Empire we saw the arrival in Britain of people born across the British Empire with multiethnic origins. For example is quite common for South all area in London that the majority of people will be of Indian descent, yet they are very typically British. In terms of the Sikh community, many were born of Indian genetic blood under the British Empire in places such as Tanzania and East Africa, but now they are just as English as those who were born from the genetic blood of somebody whose ancestral line was in England, or was a descendant of former African slaves taken to the Caribbean. It's rather interesting that Britain has been accused of being too reluctant to take on the new waves of refugees. This paper is not going to make comparisons between the quotas of a country but it is interesting to see that the presence of diverse populations does not necessarily mean it's more welcoming to new refugees because if that was true we will see greater numbers of refugees brought to England but in fact we have seen countries such as Sweden and Germany taking more refugees.

Another question is whether people should migrate throughout their life, or should find some fixed country to settle down and live. With the rise of the European Union we can see greater mobility in Europe. This has been a critical issue in the sense of identity that people have. Some refugees may live for some time in the transient country, between their dream country and their original home. Over time they may change their vision of a country based on the ethical milieu of the country, and their social acceptance. Many people in the world dream to go and live in the United States of America, and some of these cases intermediate countries are stepping stones towards migration to the United States. This is an interesting question to ask twenty years from now of the refugees of 2015, will they have integrated and be happy with their homes - or be restless because of having migrated already. A stable society may be one that has a stable population, even though it can have people coming and going, a stable demographic structure is important for the essence of a society.

Refugee camps at Calais, France on the border of the Channel tunnel to England raise another interesting issue. The British government supports construction of a refugee camp in France, for these refugees intent on entering Britain. It would seem to be better to construct the refugee camp on the other side of intended destination of the refugees which is England. Some English social workers work in these French camps with a sense of solidarity to these people. It reminds us of the Australian government policy to pay Papua New Guinea to house asylum seekers who want to come to Australia. We must see the waste of people's lives, time, and talents to have skilled people sitting in a refugee camp, just working out plans to go to the next country, when in fact they could be working to build up their destination country. The argument that is used by proponents of those who want to assist them in another country looks like the slippery slope argument that was common in bioethics. The argument is what you start opening the gate everyone will come in and there is no way to shut the gate once opened. However, these policies lead to a stronger sense of volunteering among some members of the society who disagree with the government exclusion, and they try to show their "values" of love.

\section{Harmony and other bioethics principles}

For bioethicists there are principles that can help resolve dilemmas such as autonomy, justice, beneficence, non-maleficence, dignity and integrity. However these are not sufficient to resolve the dilemmas of 
deciding limits where refugees should go and how much freedom they should have to migrate. One factor behind why people choose to live in one country is the sense of harmony. Harmony is critical to feeling at one with those places we live. My sense of belonging depends on harmony with many those around me and freedom from discrimination. Expressing love with those less fortunate than ourselves can make everyone stronger, but it is dependent upon reciprocity.

Human Security means freedom from fear, freedom from want, freedom from need, and freedom from hazard impacts. A loss of security drives people to become refugees. We also need environmental security, with protection of the environment where we live sustainably, if we will achieve a secure future. How far can we take the principle of non-maleficence as a human right? The Universal Declaration of Human Rights, the Convention on Civil and Political Rights, and the Convention on Economic and Social Rights, take seriously our duty to protect all persons. We could go further in the applications of human rights for the betterment of people and countries to protect human rights of all persons in other parts of world. There is a moral and legal obligation to human rights of persons beyond national borders, even over the principle of state sovereignty, in urgent cases. Of course the intervention in the affairs of another state need to be done carefully, but too often states have failed to intervene despite abuses of people that in war zones and zones of discrimination. International Treaties recognize the rights of refugees escaping from genocide and gross violations of human rights as legitimate persons to migrate and must at all times provide safe passage to people.

At other times however the international community has failed to learn the lessons of the history of interventions into domestic affairs of countries where that can collapse the governance structures that are critical for stability of a nation state/community, and we see severe problems that can occur with the resultant instability in Iraq and Syria for example. The lack of a respected government in a land after "liberation" from some enemy only perpetuates conflict. International mechanisms need to spend more time to focus on maintaining governments, and building government structures and a stable democracy. Failures at state building go back to colonial times, and well before. If people do have the right to live in dignity, than stable governments are surely parts of this right. One of the principles of bioethics that is critical is to respect each other to live in dignity in a community. Some communitarian societies consider it more important to build a social structure that can at times limit individual components and they tolerate the sacrifice of individuals for the state's sake of rebuilding stronger. There is clearly diversity of successful governance mechanisms, and we are still learning lessons for what is an ideal.

The undignified scenes of people who have lost most signs of dignity, as have some refugees, is a shocking wake-up call for those who wage war and play politics. At least we could say when refugees have died from their troubles they have lost the dignity. At least while they're still alive every person possesses the intrinsic dignity and this is something which is critical for us to develop society and our community. Put in the language of dignity, we could save the dignity of people by giving to others and dignity is certainly not diminished by receiving from others. Two people or two families involved in this relationship of giving and receiving, together both enhance their dignity. This form of love is the strongest sense of dignity that has existed, and had they not been involved in this free reciprocal relationship to each other their dignity would be less. Through the relationship Love in Action we can see a bioethics based on the concept of relationships has the potential to transform lives.

One of the dilemmas for the medical community in the movement of migrants is trying to treat the nature of the relationships between the healthcare professional and the migrant. The refugee in a crisis is likely to get sick and will be served if they're fortunate by the healthcare professionals of the Refugee camp or along the way. Professionals share the general ethical obligations not to extort unfair fees for the services, though it is reasonable to charge a fee if the refugee can pay. Most healthcare professionals will treat every person with equal dignity, but there are questions of privacy and the often shallow depth of relationship in a very transient refugee population if they are still migrating. In the case of notifiable diseases, a healthcare professional may have to report this person, if they have some identity, to their authorities. Privacy needs to be protected in rather challenging administrative systems, and often across national boundaries. They are obviously more complex issues of stigma and discrimination than if the patient was resident in a stable society. A refugee camp might not provide isolation facilities to protect people from infectious diseases. If an authority insists that refugees stay in the camp for isolation, or quarantine, there is an obligation to provide such facilities. Who is responsible for the infections of different refugees from others because of poor facilities? Charity organizations play a critical part in the provision of social services to refugees. If 
their funding comes from donations faraway it does provide an interesting and welcome the opportunity for Solidarity of the global community across the world than one simply organized by one Government or state.

What can we say about principle of justice? Procedural justice would establish a process for people to migrate in an orderly manner. The claims of political asylum and escapes from persecution need to be filtered out from those who are mere social economic migrants. Some of the European rules on the processing of migrants in the first European country which they enter had good intentions if sufficient resources are given to those "frontline" countries. It is ethical to have an orderly process, and this is behind the establishment of the law that would allow the refugees to be assisted in the first port of entry, and therefore the given refugee status as they move with some dignity on a route to their destination country. Certain European countries such as Italy and Greece, and Turkey, received so many refugees because they are closer to the source. These may be transit countries for many people between Asia, Africa and Europe. At the end of 2015 Europe decided it was in their interest to more strongly support the ethics of Turkey in the processing of refugees and provide financial assistance because many refugees die in their transit attempt to enter Europe.

\section{We should be able to choose our homeland}

We must set just policies that will produce a sustainable society that people, who want to live together, and call some place home, can live together happily in the future. So the interests of current and future generations is the construction of a future state which integrates people from different places, or even planets, sharing a common dream to live in this space. In the future let's hope that everyone can live where they will enjoy those around them and they will be able to spend their lives on constructive talents rejoicing together to see they chose something to enjoy the time and space which must be traversed to reach your life destination. So perhaps it is our bioethical conclusion, that there is a right for everyone to be able to say "this is my home". It is not for someone else to deny that.

\section{References}

1. Pickrell, J.A., et al. Ancient west Eurasian ancestry in southern and eastern Africa, Proceedings of the National Academy of Sciences (PNAS) 2014 111: 2632-2637; www.pnas.org/cgi/doi/10.1073/pnas.1313787111

2. Macer, DRJ. Shaping Genes: Ethics, Law and Science of Using Genetic Technology in Medicine and Agriculture. Eubios Ethics Institute, Christchurch, 1990.

3. Macer, DRJ. Bioethics is Love of Life: An Alternative Textbook. Eubios Ethics Institute, Christchurch, 1998.

4. Stannard, D. E. American Holocaust: The Conquest of the New World. Oxford University Press, New York, 1992. 